\title{
ELECTROMIC CIGARETTES: A REVIEW OF RESEARCH ON THEIR DANGER AND PRINCIPLES OF THEIR USE
}

\author{
Babyi V.F., Bren N.I., Kondratenko O.Ye.
}

\section{ЕЛЕКТРОНН СИГАРЕТИ: ОГЛЯД ДОСЛІДЖЕНЬ ЩОДО НЕБЕЗПЕКИ ТА ПРИНЦИПВВ ПОВОДЖЕЕНЯЯ З НИМИ}

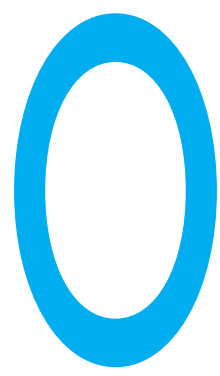

БАБІЙ В.Ф., БРЕНЬ H.I., КОНДРАТЕНКО О.є. ДУ «Інститут громадського здоров'я ім. О.М. Марзєєва НАМН України», м. Київ, Україна

УДК 615.9:616-03: 613.84

Ключові слова: електронні пристрої для доставки нікотину, електронні сигарети, небезпека, ризики. станнім часом електронні сигарети та інші електронні системи доставки нікотину стають популярними, однак їх функціонування на ринку нашої країни не врегульоване та не стандартизоване. Оскільки, згідно з роз'ясненням ДФС (ЗІР 150.05), електронні системи доставки нікотину не підпадають під визначення "тютюнові вироби" (згідно 3 визначенням, тютюнові вироби - це "вироби з тютюну або його замінників для куріння, нюхання, смоктання чи жування", а в електронних виробах використовується вдихання пари), вони не є об'єктом дії i, відповідно, до них не можуть застосовуватися вимоги законів України "Про державне регулювання виробництва і обігу спирту етилового, коньячного і плодового, алкогольних напоїв і тютюнових виробів" від 19.12.1995 № 482/95 та "Про заходи щодо попередження та зменшення вживання тютюнових виробів і їхнього шкідливого впливу на здоров'я населення" від 22.09.2005 № 2899-IV зі змінами від 2012 р. У квітні 2016 року до Верховної Ради України було подано законопроект № 4507 про внесення змін до деяких законодавчих актів України щодо державного регулювання виробництва та обігу тютюнових виробів та електронних сигарет з метою зменшення їх привабливості. Станом на січень 2017 року законопроект не прийнятий. Висновок Головного науково-експертного управління (від червня 2017 року) вказує на низку недоліків законопроекту економічного, правового та технічного характеру. Тобто стратегія поводження з цими новими для нашої країни товарами залишається донині не визначеною.

Мета. Метою даної роботи є аналіз опублікованих досліджень, що стосуються показників небезпеки електронних сигарет та ризиків для здоров'я при їх споживанні, які у подальшому можуть бути враховані при розробці політики регуляції функціонування електронних сигарет та інших електронних систем доставки нікотину на ринку України.

Електронні системи доставки нікотину як новітній вид товару (запатентовані 2006 року у Китаї) зацікавили
ЭЛЕКТРОННЫЕ СИГАРЕТЫ: ОБЗОР ИССЛЕДОВАНИЙ, КАСАЮЩИХСЯ ОПАСНОСТИ И ПРИНЦИПОВ ОБРАЩЕНИЯ С НИМИ

Бабий В.Ф., Брень Н.И., Кондратенко Е.Е. ГУ "Институт общественного здоровья им. А.Н. Марзеева НАМН Украины", г. Киев

Оборот электронных устройств для доставки никотина, в том числе электронных сигарет, на рынке Украины не урегулирован. Для определения степени возможной опасности этих изделий в данной работе представлен обзор опубликованных исследований по химическому составу аэрозолей из электронных сигарет, их опасности, по оценке индивидуальных рисков для здоровья потребителей, о принципах обращения с ними в разных странах мира.

Ключевые слова: электронные устройства для доставки никотина, электронные сигареты, безопасность, риски.
ELECTRONIC CIGARETTES: A REVIEW

OF RESEARCH ON THEIR DANGER AND PRINCIPLES OF THEIR USE

Babyi V.F., Bren N.I., Kondratenko O.Ye. SI "O.M. Marzeiev Institute for Public Health, NAMSU", Kyiv

In Ukrainian market the turnover of electronic devices for nicotine delivery, including electronic cigarettes, has not been controlled. In this work we present the review of published studies about chemical composition of aerosols from electronic cigarettes, their danger, individual risk to the health of consumers, about principles of their using in different countries of the world in order to determine the degree of possible danger from these products.

Keywords: electronic devices

for nicotine delivery, electronic cigarettes, safety, risk.

( Бабій В.Ф., Брень Н.І., Кондратенко О.Є. СТАТТЯ, 2018. 
дослідників в усьому світі. Слід зауважити, що дана робота, 3 огляду на зрозумілі обмеження у рамках журнальної статті, не охоплює всього об'єму наявної літератури.

З 2006 року, коли електронні сигарети з'явилися на світовому ринку, спостерігається постійне зростання обсягів їх продажу, при цьому деякі дослідники повідомляють, що ці продукти стають загрозою для збуту традиційних сигарет [1]. Таке зростання продажів відображається у даних опитувань населення, особливо країн з високим рівнем доходу [2-4] і пов'язане з перевагами електронних сигарет, що несуть менші ризики для здоров'я порівняно з традиційними сигаретами через відсутність у них токсичних хімічних речовин, які утворюються у великих кількостях при згорянні тютюну.

Перші дослідження хімічного складу аерозолів електронних сигарет були здійснені авторами [5]. Максимальна температура активованих електронних сигарет у цих дослідженнях була $54^{\circ} \mathrm{C}$, що становить приблизно 5-10\% від температури палаючої тютюнової сигарети. Токсичні хімічні компоненти, такі як важкі метали, канцерогенні поліциклічні ароматичні вуглеводні та феноли не були виявлені, за винятком слідів ртуті, формальдегіду та ацетальдегіду. Лаугесен оцінив ці викиди за шкалою інтенсивності викидів шкідливих речовин у 0 балів в електронних сигаретах порівняно зі 100-134 балами для тютюнових сигарет. 2009 року Управління 3 контролю над продуктами та ліками США (FDA) також провело хімічний аналіз 18 рідин для електронних сигарет. Було виявлено наявність специфічних для тютюну нітрозамінів (TSNAs) та діетиленгліколю в одному із зразків, але у кількостях, що не можуть завдавати шкоди за нормального використання. Інше дослідження виявило невелику кількість аміно-тандалафілу та римонабату [6, 7]. Автори дійшли висновку, що, судячи з даних хімічного аналізу, електронні сигарети $€$ набагато менш шкідливими порівняно з тютюновими сигаретами. Найбільш повне дослідження на TSNAs було виконано групою дослідників [8], які оцінювали 105 рідин для електронних сигарет, отриманих від місцевих роздрібних продавців. У середньому вони знайшли 12.99

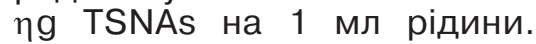
Розраховане щоденне навантаження нітрозамінів із тютюнових сигарет на споживача (з середнім споживанням 15 сигарет на добу) оцінюється у 1800 разів вищим, ніж в електронних сигаретах [9]. Аналізуючи вміст нікотину та продуктів його деградації у 20 зразках електронних сигарет, автори виявили, що рівні нікотину у них становлять 85-121\% від рівня нікотину у традиційних сигаретах, тоді як продукти деградації нікотину були присутні на рівні 0-4,4\%[10].

Також проводилися хімічні аналізи для виявлення карбонільних сполук. Відомо, що термічна деградація пропіленгліколю та гліцерину може призвести до викидів таких токсичних сполук, як альдегіди $[11,12]$. Фарсалінос та його колеги оцінювали емісію 15 карбонілів 312 марок електронних сигарет [13]. Для отримання пари дослідники використовували курильну машину і дотримувалися режиму 1,8-секундних затяжок 3 інтервалом у 10 секунд. У результаті з 15 карбонілів було виявлено лише три (формальдегід, ацетальдегід та акролеїн), рівні яких були у 9-450 разів нижчими порівняно 3 викидами із тютюнових сигарет. Крім того, вони дослідили наявність 11 летких органічних сполук, у тому числі толуолу та ксилолу, рівні яких були у 120 разів меншими порівняно 3 тютюновими сигаретами. Оцінюючи ризик для споживачів на основі стандартів впливу, наприклад граничного порогового значення TLVs, дослідники дійшли висновку, що вплив токсичних хімічних речовин 3 електронних сигарет $є$ набагато нижчим порівняно з традиційними сигаретами. Встановлено, що прогнозний вплив від пари з електронних сигарет становить <1\% від впливу тютюнових сигарет. Крім того, понад 4000 хімічних речовин, присутніх у тютюновому димі, цілком відсутні у парах електронних сигарет, а вміст токсичних компонентів $€$ значно меншим, ніж у сигаретах, і присутній на рівні, який навряд чи становить значний ризик для здоров'я як для користувача, так і для пасивного курця [14-16].

Однак $€$ дані про те, що коротке та середньострокове використання електронних сигарет може бути пов'язаним з деякими побічними ефектами [17, 18], а довгострокові ефекти після 12 місяців вживання не досліджені. Разом 3 тим, у звіті Королівського коледжу лікарів Великої Британії 2016 року зроблено висновок, що використання електронних сигарет, ймовірно, буде значно безпечнішим, ніж паління. А деякі дослідники навіть стверджують, що клінічні, хімічні та токсикологічні дані і результати опитувань споживачів часто були некоректно представлені або неправильно витлумачені органами охорони здоров'я та регуляторами тютюну таким чином, що потенціал шкідливих наслідків використання електронних сигарет $€$ значною мірою перебільшеним і ризики, пов'язані з їх використанням, є незначними порівняно з руйнівними наслідками паління [19].

Слід зазначити, що було проведено низку клінічних досліджень. При дослідженні групи з 111 користувачів електронних сигарет, які повністю кинули палити і щоденно користувалися електронними сигаретами протягом середнього періоду у 8 місяців, було зафіксовано подразнення горла та кашель - найпоширеніші побічні ефекти [20]. Подібні висновки були виявлені в опитуваннях [21-23]. В аналогічних дослідженнях [24] повідомлялося про клінічно значуще покращання стану здоров'я 
Інституту кардіології імені М.Д. Стражеска було здійснено 6-місячне дослідження здоров'я курців при переході від звичайних сигарет на електронні. Згідно з результатами досліджень перехід курців на електронні системи доставки нікотину дозволяє уникнути ушкодження судинного ендотелію та розвитку проатерогенних змін метаболізму ліпідів та ліпопротеїдів крови, що призводить до скорочення ризику розвитку серцевосудинних захворювань. Дослідники також зафіксували, що використання електронних замінників у поєднанні з традиційним палінням тютюну (подвійне використання) суттєво знижує позитивний ефект [29]. Нині результати цих досліджень є чи не єдиною вітчизняною науковою оцінкою впливу електронних систем доставки нікотину на здоров'я курців.

Дослідження [30] оцінювало гострий ефект використання тютюну та електронних сигарет на кількість білих кров'яних тілець. Паління однієї тютюнової сигарети викликало негайне підвищення рівня білих кров'яних тілець нейтрофілів і лімфоцитів. А після використання електронних сигарет таких явищ не спостерігалося. У результаті електронні сигарети були рекомендовані курцям та колишнім курцям як замінники звичайних сигарет або для запобігання рецидиву куріння, оскільки, на думку дослідників, ризик вживання електронних сигарет має оцінюватися у порівнянні з ризиком продовження або рецидиву паління тютюнових сигарет, а також у зв'язку з низькою ефективністю інших ліків для припинення куріння [31-33].

Наразі існує загальний консенсус, що використання електронних сигарет менше шкодить користувачам, ніж тютюнові сигарети [34], проте ті, хто закликає до жорсткого регулювання їх використання $[35,36]$, наводять посилання на відсутність заходів контролю якості, можливу шкоду довгострокового вживання, а також на побоювання, що вживання електронних сигарет може бути поштовхом до початку тютюнопаління. Проте інші не підтверджують наявність цих проблем та вказують на те, що потенційні переваги перевершують потенційні недоліки [34, 37].

у доповіді ВООЗ вказано: „якщо значна більшість людей, що палять тютюн, які не можуть або не хочуть відмовитися від паління, перейдуть на будь-яке 3 альтернативних джерел доставки нікотину, що становлять менше небезпек для здоров'я, і у кінцевому рахунку відмовляться від його вживання, це буде суттєвим досягненням у галузі охорони здоров'я" [38].

На основі проведених досліджень у розвинених країнах розроблено принципи поводження з цими новими товарами. Дані принципи базуються на тому, що будь-які регуляторні рішення не повинні ставити під загрозу варіативність вибору для споживачів, а також на тому, що потрібно уникати нераціонального застосування принципу запобіжного заходу [39].

Разом 3 тим, виробники повинні надавати докази якості інгредієнтів, що використовуються, і проводити випробування на ефективність та безпеку своїх продуктів.

Регуляторні підходи, що використовуються у різних країнах, нині дещо різні. Однак це переважно сертифікація та різного роду обмеження. Згідно з даними, опублікованими у мережі Інтернет, до заборони електронних сигарет вдаються лише деякі країни, такі як Таїланд, Бразилія. Із країн Євросоюзу електронні сигарети заборонені у Бельгії. Готувалися ввести заборону в Італії, але є відомості про те, що нині у цій країні відмовилися від повної заборони електронних сигарет та ввели лише низку обмежень. Виходячи 3 того, що ці продукти містять нікотин, Американська харчова та лікарська асоціація класифікувала їх як тютюнові вироби та впроваджує акцизи на їх продаж та використання (FDA 2016). У Великобританії електронні сигарети, на думку фахівців, наприклад головного лікаря уряду, повинні використовуватися у медичних цілях як спосіб кинути палити і продаватися за рецептом лікаря. Цю ідею підтримує Депар- 
тамент охорони здоров'я Англії. У Франції 2016 року прийнято указ, згідно з яким діяльність торговельних закладів цими товарами підлягає сертифікації, їхні власники щорічно повинні сплачувати державний збір за кожен вид продукту. 32017 року у Фінляндії заборонено купувати рідини 3 нетютюновими смаками через Інтернет і поштовою пересилкою. У Росії розглядається законопроект, який вводить акциз на продаж пристроїв і рідин.

у лютому 2014 року Європейський парламент затвердив Директиву Європейського Союзу щодо тютюнових виробів, яка визначає електронні сигарети 3 концентрацією нікотину до 20 мг/мл як тютюнові вироби, та сформулював рекомендації щодо їх використання, зокрема такі:

口 заборонити використання електронних сигарет у будьякому місці, де заборонене використання звичайних сигарет;

$\square$ заборонити продаж електронних сигарет будь-кому, хто не може легально купувати сигарети, або у будь-яких місцях, де забороняється продаж звичайних сигарет;

п привести маркетинг електронних сигарет до такого ж рівня обмежень, що застосовуються до традиційних сигарет;

口 заборонити використання приваблюючих ароматизаторів в електронних сигаретах, зокрема цукеркових та алкогольних;

- заборонити стверджувати, що електронні сигарети $€$ ефективними засобами припинення паління, поки виробники не нададуть достатніх доказів того, що електронні сигарети можуть бути ефективно використані для припинення куріння;

口 встановити стандарти регулювання матеріалів та сировини для електронних сигарет.

\section{Висновки}

Обіг електронних сигарет на ринку України є неврегульованим та нестандартизованим. Принципи поводження 3 ними нині не визначено.

Відповідно до оприлюднених результатів досліджень пере- важної кількості дослідників вживання електронних сигарет несуть менші ризики для здоров'я порівняно 3 традиційними тютюновими сигаретами.

Ефективність використання електронних сигарет в якості засобу для припинення паління тютюну остаточно не доведено.

Уряди більшості країн, за невеликим виключенням, не вдаються до заборони електронних сигарет. Регуляторні підходи, що використовуються у різних країнах, зводяться переважно до сертифікації та різного роду обмежень.

ЛІТЕРАТУРА

1. Herzog B. E-Cigs revolutionizing the tobacco industry. Convenience Store News. 2013. № 49 (9). P. 94-96.

2. Agaku I.T. , King B.A., Husten C.G., Bunnell R., Ambrose B.K, Hu S.S. Tobacco product use among adults United States, 2012-2013. Morbidity \& Mortality Weekly Report. 2014. № 63 (25). P. 542-547.

3. Ayers J.W., Ribisl K.M., Brownstein J.S.Tracking the rise in popularity of electronic nicotine delivery systems (electronic cigarettes) using search query surveillance. American Journal of Preventive Medicine. 2011. № 40 (4). P. 448-453.

4. Gallus S., Lugo A. Pacifici R., Pichini S., Colombo P., Garattini S. La Vecchia C. E-Cigarette awareness, use, and harm perception in Italy: a national representative survey. Nicotine \& Tobacco Research. 2014.

Vol. 16. P. 1541-1548.

5. Laugesen M. Safety Report on the Ruyan e-cigarette Cartridge and Inhaled Aerosol : Ruyan Cartridge Report. 2013. URL : http://www. healthnz.co. nz/RuyanCartridgeReport30Oct-08.pdf

6. Lisko J.G., Hang Tran, Stanfill S.B., Blount B.C. and Watson C.H. Chemical Composition and Evaluation of Nicotine, Tobacco Alkaloids, $\mathrm{pH}$ and Selected Flavors in e-Cigarette Cartridges and Refill Solutions. Nicotine Tob Res. 2015. Vol. 17 (10). P. 12701278.
7. Hadwiger M., Trehy M., Ye W., Moore T., Allgire J., Westenberger B. Identification of amino-tadalafil and rimonabant in electronic cigarette products using high pressure liquid chromatography with diode array and tandem mass spectrometric detection. J.Chromatogr. 2013. № 1217. P. 7547-7555.

8. Kim H., Shin H.

Determination of tobacco-specific nitrosamines in replacement liquids of electronic cigarettes by liquid chromatography-tandem mass spectrometry. J. Chromatogr. 2013.

№ 1291. P. 48-55.

9. Farsalinos K., Romagna G., Voudris V. Authors miss the opportunity to discuss important public health implications. J. Chromatogr. A. 2013

№ 1312. P. 155-156.

10. Etter J., Zдther E., Svensson S. Analysis of refill liquids for electronic cigarettes. Addiction. 2013. № 108.

P. 1671-1679.

11. Antal M., Mok W., Roy J., T-Raissi A. Pyrolytic sources of hydrocarbons from biomass. J. Anal. Pyrol. 1985. № 8. P. 291-303.

12. Stein Y., Antal M., Jones M. A study of the gas-phase pyrolysis of glycerol. J. Anal. Appl. Pyrol. 1983. № 4. P. 283-296

13. Farsalinos K., Romagna G., Tsiapras D., Kyrzopoulos S., Voudris V. Evaluation of electronic cigarette use (vaping) topography and estimation of liquid consumption: implications for research protocol standards definition and for public health authorities' regulation. Int. J. Environ. Res. Public Health. 2013. № 10. P. 25002514.

14. Burstyn I. Peering through the mist: Systematic review of what the chemistry of contami- 
nants in electronic cigarettes tells us about health risks. BMC Public Health. 2014. № 14. P. 18.

15. Hajek P., Etter J.-F., Benowitz N., Eissenberg T., McRobbie $\mathrm{H}$. Electronic cigarettes: review of use, content, safety, effects on smokers and potential for harm and benefit. Addiction. 2014. № 109 (11). P. 1801-1810.

16. McNeill A., Brose L.S., Calder R., Hitchman S.C., Hajek P., McRobbie H. E-cigarettes: an evidence update: $\mathrm{A}$ report commissioned by Public Health England. 2015. URL : www.gov.uk//government/uplo ads/system/uploads/attachment data/file/457102/Ecigare ttes_ān_evidence_update_A re port commissioned by Public Health England FINAL.pdf

17. Bullen C., Howe C., Laugesen M., McRobbie H., Parag V., Williman J. Electronic cigarettes for smoking cessation: a randomised controlled trial. Lancet. 2013. № 382

P. 1629-1637.

18. Caponnetto P., Auditore R., Russo C., Cappello G., Polosa R. Impact of an electronic cigarette on smoking reduction and cessation in schizophrenic smokers: a prospective 12-month pilot study. Int J Environ Res Public Health. 2013. № 10. P. 446-461.

19. Polosa R. and Caponnetto P. Time for evidence-based e-cigarette regulation. Lancet Oncol. 2013. № 14 (13).

\section{P. e582-583.}

20. Farsalinos K., Romagna G., Tsiapras D., Kyrzopoulos S., Voudris V. Evaluating nicotine levels selection and patterns of electronic cigarette use in a group of "vapers" who had achieved complete substitution of smoking.
Subst Abuse. 2013. № 7.

P. 139-146.

21. Dawkins L., Corcoran O. Acute electronic cigarette use: nicotine delivery and subjective effects in regular users. Psychopharmacology (Berl). 2013. № 231. P. 401-407.

22. Dawkins L., Turnern J., Roberts A., Soar K. Vaping' profiles and preferences: an online survey of electronic cigarette users. Addiction. 2013. № 108. P. 1115-1125.

23. Etter J., Bullen C.

Electronic cigarette: users profile, utilization, satisfaction and perceived efficacy. Addiction. 2011. № 106. P. 2017-2028.

24. Caponnetto P., Campagna D., Cibella F., Morjaria J., Caruso M., Russo C. Efficiency and safety of an electronic cigarette (ECLAT) as tobacco cigarettes substitute: a prospective 12-month randomized control design study. PLoS One. 2013. Vol. 8 (6). e66317. doi: 10.1371/journal.pone.0066317

25. Bullen C., Howe C., Laugesen M., McRobbie H., Parag V., Williman J. Electronic cigarettes for smoking cessation: a randomised controlled trial. Lancet. 2013. № 382.

P. 1629-1637.

26. Flouris A., Chorti M., Poulianiti K., Jamurtas A., Kostikas K., Tzatzarakis M. Acute impact of active and passive electronic cigarette smoking on serum cotinine and lung function. Inhal Toxicol. 2013. № 25. P. 91-101.

27. Farsalinos K., Tsiapras D., Kyrzopoulos S., Stefopoulos C., Spyrou A., Tsakalou M.

Immediate effects of electronic cigarette use on coronary circulation and blood carboxyhemoglobin levels: comparison with cigarette smoking. Eur. Heart J. 2013. № 34. P. 13.

28. Van Staden S.,

Groenewald M., Engelbrecht R., Becker P., Hazelhurst L.

Carboxyhaemoglobin levels, health and lifestyle perceptions in smokers converting from tobacco cigarettes to electronic cigarettes. S. Afr. Med. J. 2013. № 103. P. 865-868.

29. Кваша Е. А., Срибная О.В., Смирнова И.П., Третяк И.В., Бородай А.А. Оценка влияния электронных систем доставки никотина на риск сердечнососудистых заболеваний на основе функции эндотелия и определяющих ее факторов. Медична газета "Здоров'я України 21 століття". 2017. № 11-12 (408-409). URL : http://health-ua.com/newspaper/med_gaz_zu/29765medichna-gazeta-zdorovyaukrani-21-storichchya--1112408409-cherven-2017-r

30. Flouris A., Poulianiti K., Chorti M., Jamurtas A.

Kouretas D., Owolabi E. Acute effects of electronic and tobacco cigarette smoking on complete blood count. Food Chem Toxicol. 2012. № 50.

P. 3600-3603.

31. Moore D., Aveyard P., Connock M., Wang D., FrySmith A., Barton P.

Effectiveness and safety of nicotine replacement therapy assisted reduction to stop smoking: systematic review and meta-analysis. BMJ. 2009. Vol. 338. b1024

32. Rigotti N., Pipe A.

Benowitz N., Arteaga C., Garza D., Tonstad S. Efficacy and safety of varenicline for smoking cessation in patients with cardiovascular disease: A randomized trial. Circulation. 2010. № 121. P. 221-229.

33. Yudkin P., Hey K., Roberts S., Welch S., Murphy M., Walton R. Abstinence from smoking eight years after participation in randomised controlled trial of nicotine patch. BMJ. 2003. Vol. 327. P. 28-29.

34. Royal College of Physicians. Nicotine without smoke: Tobacco harm reduction. London : RCP, 2016. 206 p.

35. Grana R., Benowitz N., Glantz S.A. E-cigarettes: a scientific review. Circulation. 2014. № 129 (19).

P. $1972-1986$.

36. McKee M., Daube M., Chapman S. E-cigarettes should be regulated. Medical Journal of Australia. 2016. № 204 (9). P. 331.

37. Farsalinos K.E., Polosa R. Safety evaluation and risk assessment of electronic cigarettes as tobacco cigarette substitutes: a systematic review. Therapeutic Advances in Drug Safety. 2014. № 5 (2). P. 67-86.

38. Электронные системы доставки никотина и электронные системы доставки продуктов, не являющихся никотином : Доклад ВОЗ. 
2016. URL : http://www.who.int/ fctc/cop/cop7/FCTC_COP_7_1 1 RU.pdf

39. Saitta D., Ferro G., Polosa R. Achieving appropriate regulations for electronic cigarettes. Ther Adv Chronic Dis. 2014. 5 (2). 50-61. doi: 10.1177/2040622314521271 REFERENCES

1. Herzog B. Convenience Store News. 2013 ; 49 (9) : 94-96.

2. Agaku I.T., King B.A., Husten C.G., Bunnell R., Ambrose B.K. and Hu S.S. Morbidity \& Mortality Weekly Report. 2014; 63(25) : 542-547.

3. Ayers J.W., Ribisl K.M. and Brownstein J.S. American Journal of Preventive Medicine. 2011 ; 40(4) : 448-453.

4. Gallus S., Lugo A., Pacifici R., Pichini S., Colombo P., Garattini S. and La Vecchia C. Nicotine \& Tobacco Research. $2014 ; 16: 1541-1548$.

5. Laugesen M. Safety Report on the Ruyan e-cigarette Cartridge and Inhaled Aerosol : Ruyan Cartridge Report. 2013. URL : http://www.healthnz. co.nz /RuyanCartridgeReport 30-Oct-08.pdf

6. Lisko J.G., Hang Tran, Stanfill S.B., Blount B.C. and Watson C.H. Nicotine Tob. Res. $2015 ; 17$ (10) : 1270-1278.

7. Hadwiger M., Trehy M., Ye W., Moore T., Allgire J. and Westenberger B. J.Chromatogr. 2013 ; 1217 : 7547-7555.

8. Kim H. and Shin H. J. Chromatogr. 2013 ; 1291 : 48-55.

9. Farsalinos K., Romagna G. and Voudris V. J. Chromatogr $A$. 2013 ; 1312 : 155-156.

10. Etter J., Zдther E. and Svensson S. Addiction. 2013 ; $108: 1671-1679$.

11. Antal M., Mok W., Roy J. and T-Raissi A. J. Anal. Appl. Pyrol. 1985 ; 8 : 291-303.

12. Stein Y., Antal M. Jones M. J. Anal. Appl. Pyrol. 1983 ; 4 : 283-296.

13. Farsalinos K., Romagna G., Tsiapras D., Kyrzopoulos S. and Voudris V. Int. J. Environ. Res. Public Health. $2013 ; 10: 2500-2514$.

14. Burstyn I. BMC Public Health. 2014 ; 14 : P. 18.

15. Hajek P., Etter J.-F., Benowitz N., Eissenberg T. and McRobbie H. Addiction. 2014 ; 109 (11) : 1801-1810.

16. McNeill A., Brose L.S., Calder R., Hitchman S.C.,
Hajek P. and McRobbie $\mathrm{H}$. E-Cigarettes: an Evidence Update: A Report Commissioned by Public Health England. 2015. URL : www.gov.uk//government/uplo ads/system/uploads/attachment_data/file/457102/Ecigare ttes_an_evidence_update_A_re port_commissioned_by_Püblic Health_England_FINAL.pdf

17. Bullen C., Howe C.,

Laugesen M., McRobbie H., Parag V. and Williman J. Lancet. 2013 ; 382 : 1629-1637.

18. Caponnetto P., Auditore R., Russo C., Cappello G. and Polosa R. Int. J. Environ. Res.

Public Health. 2013 ; 10 : 446-461.

19. Polosa R. and Caponnetto P. Lancet Oncol. 2013 ; 14 (13) : e582-583.

20. Farsalinos K.,

Romagna G., Tsiapras D. Kyrzopoulos S. and Voudris V. Subst Abuse. 2013 ; 7 : 139146.

21. Dawkins L. and Corcoran O. Psychopharmacology (Berl). 2013 ; 231 : 401-407.

22. Dawkins L., Turnern J., Roberts A. and Soar K. Addiction. 2013 ; 108 : 1115-1125.

23. Etter J. and Bullen C. Addiction. 2011 ; 106 : 2017-2028.

24. Caponnetto P., Campagna D., Cibella F., Morjaria J., Caruso M. and Russo C. PLoS One. 2013 ; 8 (6) : e66317. doi: 10.1371/journal.pone.0066317

25. Bullen C., Howe C., Laugesen M., McRobbie H., Parag V. and Williman J. Lancet. 2013 ; 382 : 1629-1637.

26. Flouris A., Chorti M. Poulianiti K., Jamurtas A., Kostikas K. and Tzatzarakis M. Inhal. Toxicol. 2013; 25 : 91-101.

27. Farsalinos K., Tsiapras D., Kyrzopoulos S., Stefopoulos C., Spyrou A., Tsakalou M. Eur. Heart. J. 2013 ; 34 : 13.

28. Van Staden S., Groenewald M., Engelbrecht R., Becker P. and Hazelhurst L. S Afr. Med. J. 2013 ; 103 : 865-868.

29. Kvasha E. A., Sribnaya O.V., Smirnova I.P., Tretiak I.V. and Boroday A.A. Otsenka vliyaniya elektronnykh system dostavki nikotina na risk serdechnososudistykh zabolevaniy na osnove funktsii endoteliya i opredeliayushchikh ee faktorov [Assessment of the Impact of Nicotine Delivery Electronic Systems on the Risk of Cardiovascular Diseases on the
Basis of the Endothelium and Factors Determining It]. Medychna hazeta "Zdorovia Ukrainy 21 stolittia". 2017 ; 11 12 (408-409). URL : http:// health-ua.com/newspaper/ med_gaz_zu/29765-medichnagazeta-zōorovya-ukrani-21storichchya--1112-408409cherven-2017-r (in Russian).

30. Flouris A., Poulianiti K., Chorti M., Jamurtas A., Kouretas D. and Owolabi E. Food Chem Toxicol. 2012 ; 50 : 3600-3603.

31. Moore D., Aveyard P., Connock M., Wang D., FrySmith A. and Barton P. BMJ. 2009 ; 338 : b1024.

32. Rigotti N., Pipe A., Benowitz N., Arteaga C., Garza D. and Tonstad S. Circulation. $2010 ; 121$ : 221-229.

33. Yudkin P., Hey K., Roberts S., Welch S., Murphy M. and Walton R. BMJ. 2003 ; 327 : 28-29.

34. Royal College of Physicians. Nicotine without smoke: Tobacco harm reduction.

London : RCP; 2016 : 206 p.

35. Grana R., Benowitz N. and Glantz S.A. Circulation. 2014 ; 129(19) : 1972-1986.

36. McKee M., Daube M. and Chapman S. Medical Journal of Australia. 2016 ; 204(9) : 331. doi: 10.5694/mja16.00024

37. Farsalinos K.E. and Polosa R. Therapeutic Advances in Drug Safety. 2014 ; 5(2): 67-86.

38. WHO Electronic Nicotine Delivery Systems and Electronic Non-Nicotine Delivery Systems (ENDS/ENNDS) : Report. 2016. URL : http://www. who.int/fctc/ cop/cop7/FCTC_COP_7_11 EN.pdf

39. Saitta D., Ferro G. and Polosa R. Ther Adv Chronic Dis. 2014 ; 5 (2) : 50-61. doi: $10.1177 / 2040622314521271$

Надійшло до редакції 13.12.2017 